\title{
Скринінг раку ротової порожнини: актуальність питання, поточний стан проблеми та перспективи розвитку (огляд літератури)
}

\author{
Буковинський державний медичний університет, Чернівці \\ Одержано 01.10.2019 \\ Прийнято до друку 02.01.2020 \\ DOI: $10.32471 /$ clinicaloncology.2663-466X.36-4.26809
}

\begin{abstract}
Це дослідження присвячене вивченню проблеми раку ротової порожнини, а також методам скринінгу, що існують для такого виду онкологічних захворювань. Мета і об'єкт дослідження. Оцінити методи скринінгу, їх специфічність і чутливість, а також доцільність та відповідність існуючих методик світовим вимогам до скринінгових програм та встановити перспективи подальшого наукового пошуку в напрямку розробки адекватного скринінгу. Методом дослідження став аналіз літературних джерел та пошук даних, які відповідають вказаній тематиці у різних науково-методичних базах. У результаті дослідження було встановлено, що існуючі спроби проведення як організованих, так і опортуністичних скринінгових програм показали свою неефективність та не були прийняті ні на одному з рівнів організації системи охорони здоров'я. Основним методом скринінгових програм було проведення фізикального обстеження ротової порожнини у поєднанні з різними допоміжними методами. Усі ці методики показали недостатню специфічність та чутливість. Висновки. Жоден з відомих скринінгових методів не відповідає вимогам та не є достатньо рентабельним, чутливим та малоінвазивним. Таким чином, це дослідження підкреслює важливість пошуку нового методу скринінгу раку ротової порожнини.
\end{abstract}

Ключові слова: рак ротової порожнини; скринінг; методи скринінгу; скринінгові програми; фактори ризику.

\section{АКТУАЛЬНІСТЬ}

Рак ротової порожнини (РРП) у світі щороку діагностують у більш ніж 300 тис. пацієнтів, а близько 150 тис. пацієнтів кожного року помирають внаслідок цієї патології. Лише в Україні за 2016 р. від РРП померло 1603 пацієнти, і цей показник займає 24-те місце у світі. За останніми даними Національного інституту раку, у 2017 р. на обліку в Україні знаходилися 20825 хворих на РРП (з них 14596 - чоловіки, 6229 - жінки). Показник захворюваності на РРП в Україні становить 3,9. При цьому серед усіх хворих на РРП більше ніж 56\% можуть померти протягом найближчих 5 років, $43 \%$ - протягом найближчих 10 [17, 61, 62].

Висока смертність внаслідок РРП зумовлена складністю діагностики та пізнім виявленням цього захворювання, що пояснюється низкою факторів. Перш за все, це відсутність болю чи інших симптомів, які змусили б хворого вчасно звернутися до лікаря за консультацією. Іншою перешкодою для вчасної діагностики, за даними досліджень Сеульського національного університету, є зв'язок цього захворювання з вірусом папіломи людини (ВПЛ) 16 (Human Papillomavirus 16 - HPV16), що спричиняє підвищення частоти захворюваності, особливо у задніх відділах ротової порожнини, де найчастіше не спостерігаються видимі зміни слизової, а отже, і відсутні ранні ознаки злоякісного процесу. Також причиною є відсутність державних програм, які б забезпечували неопортуністичні, тобто невипадкові, виявлення РРП навіть у найбільш розвинутих країнах світу [18, 34].

Для розуміння тенденцій та зв'язку РРП з географічними та соціальними показниками було проведено аналіз даних різних національних реєстрів країн світу, що дозволив встановити наступний факт: навіть у розвинутих країнах (країни Європи, Сполучені Штати Америки, Канада, Японія) рівень смертності внаслідок РРП в останні роки залишається стабільно високими. Крім того, незважаючи на деякий прогрес у боротьбі з РРП, загальні показники виживаності в цих країнах протягом 5 років істотно не покращилися. Натомість у таких країнах, як Шотландія, Фінляндія, країни східної Європи (Польща, Чехія, Словенія, Угорщина), визначається підвищення захворюваності на РРП, а у більшості східноєвропейських країн спостерігається підвищення смертності внаслідок РРП [49].
Відповідно до даних ВООЗ РРП найчастіше відмічають у пацієнтів віком старше 50 років, а частота РРП прямо пропорційна віку. Так, деякі дослідження показують, що лише менш ніж 6\% випадків РРП виявляють у хворих віком молодше 40 років. Однак впродовж останніх років ці показники $є$ сумнівними, оскільки прослідковується стійка тенденція до підвищення частоти РРП і серед молодого населення. Окрім цього, визначається асоціація між віком та такими факторами ризику, як куріння та вживання алкоголю, які, за даними Міжнародного агентства з дослідження раку, пов'язують з 75-90\% випадків онкопроцесів ротової порожнини [24].

3 огляду на вищесказане, РРП найчастіше виявляють уже за наявності метастазування в лімфатичні вузли шиї. На цій стадії захворювання прогноз є значно гіршим, адже, окрім метастазування, існує високий ризик глибокого проростання пухлини в прилеглі тканини. За даними досліджень Р. Вебера та групи вчених Філадельфійського медичного університету (University of Pennsylvania Medical Center, Ravdin, Philadelphia), щонайменше у 50\% пацієнтів з РРП розвиваються локальні та віддалені метастази. Наразі виявляють РРП переважно стоматологи та сімейні лікарі, проте особливості цієї ділянки та складність процесу унеможливлюють встановлення діагнозу РРП на рівні цих спеціалістів, що, у свою чергу, збільшує кількість пацієнтів із пізніми стадіями. Крім того, гематогенний та лімфогенний шляхи поширення дозволяють раку метастазувати далеко за межі ділянки голови та шиї, при цьому для РРП характерне швидке поширення з током лімфи навіть на ранніх стадіях захворювання. Статистика свідчить, шо серед пацієнтів здіагностованим ураженням лімфатичних вузлів лише 25-40\% доживають до 5 років 3 моменту встановлення діагнозу, натомість аналогічний показник серед пацієнтів без метастазування у лімфатичні вузли становить $90 \%$ [12, 45, 50, 52, 61].

Наведені дані вказують на необхідність вирішення проблеми пізньої діагностики РРП шляхом пошуку та впровадження методів скринінгу та ранньої діагностики цієї патології. Отже, актуальним є розроблення скринінгових методів виявлення РРП з метою запобігання пізнім ускладненням і метастазуванню пухлини та, як наслідок, зменшення летальності цього захворювання. 


\section{META}

Оцінити методи скринінгу РПП, які існують на сьогодні, їх специфічністьі чутливість, розглянути перспективи подальшого наукового пошуку в напрямку розробки адекватного скринінгу цієї онкопатології.

\section{МАТЕРІАЛИ I МЕТОДИ}

Для досягнення поставленої мети було проведено аналіз публікацій наукових досліджень в наукометричних базах даних, таких як EBSCO host, Web of Science, Google Scholar.

\section{РЕЗУЛЬТАТИ ДОСЛІДЖЕННЯ ТА ЇХ ОБГОВОРЕННЯ}

У 1968 р. J. Wilson та G. Jungner вперше було вжито термін «скринінг», вони ж і перерахували основні властивості програми скринінгу здоров'я, наявність яких є важливою для забезпечення максимальних результатів програми в галузі охорони здоров'я на рентабельній основі (витрати на скринінг компенсуються економією на лікуванні). Ці критерії видозмінювалися протягом десятиліть, аби відобразити більш точні доказові стандарти, необхідні для доведення ефективності іпідвищення рентабельності без отримання додаткових ризиків для життя [59].

Так, Національний скринінговий комітет Великої Британії (National Screening Committee - NSC) з 2015 р. вимагає виконання 7 критеріїв, перш ніж запустити державну програму скринінгу, яку можна було б фінансувати та впроваджувати на державному рівні. Національний інститут раку США(National Cancer Institute - NCI) та Спеціальна група з профілактичних хвороб США (Centers for Disease Control and Prevention) мають аналогічні критерії.

Наразі розповсюдженими є дві моделі скринінгових програм: організовані та опортуністичні. Організована скринінгова програма - це централізовано профінансована програма, що має на меті проаналізувати групи населення, які мають високий ризик виникнення певної патології, до них зазвичай входять без скарг на здоров'я особи, відібрані за статтю та віком. Їх запрошують на скринінгові дослідження, після чого ведеться запис даних шодо них та нагляд кожної особи, яка пройшла такі дослідження. Організована скринінгова програма фінансується державою або іншими організаціями охорони здоров'я тільки після доведення іiі ефективності в рандомізованих клінічних дослідженнях та економічної рентабельності. Натомість опортуністичні скринінгові програми проводяться децентралізовано та виконуються в кабінетах різних спеціалістів за бажанням пацієнта або за підозрою лікаря. Основною метою обох моделей скринінгових програм є зниження смертності населення за рахунок виявлення захворювань на ранніх доклінічних стадіях та їх подальше лікування. У світі існують тільки 3 доведені скринінгові програми: скринінг грудної залози шляхом мамографії, цитологічний скринінг раку шийки матки та скринінг колоректального раку шляхом визначення прихованої крові у випорожненнях [35].

У деяких випадках РРП передує потенційно злоякісний стан (ПЗС). Найбільш поширеними станами, визнаними як потенційно злоякісні, є лейкоплакія та еритроплакія, які, у свою чергу, можуть мати характерні клінічні особливості. Хоча патогенез цієї хвороби до кінця не вивчений, у ході аналізу літератури було виявлено одну спробу щодо проведення організованої скринінгової програми, яка являла собою рандомізоване контрольоване дослідження і базувалася на виявленні ПЗС. Його проводила група вчених з Індії в Північному Трівандрумі, штат Керала, з 1996 до 2004 р. 3 метою зниження собівартості дослідження скринінгові огляди для виявлення цих ПЗС виконували не дипломовані медичні фахівці, а особи, які пройшли спеціальн навчання протягом 3 міс з вивчення соціально-демографічних особливостей та візуальної експертизи ПЗС РРП, у тому числі білих та червоних уражень, підслизового фіброзу та виразки, які вказували б на злоякісні новоутворення. Протягом 15 років тривали 4 етапи скринінгу, завершені в 1998, 2002, 2004 та 2009 р. $[39,43,44,48]$.

Детальний аналіз результатів було проведено у 2005 р. після закінчення 3 етапів обстеження, наступний (четвертий) аналітичний етап скринінгу проводився у 2013 р. Після 4 раундів спостерігалося значне покращення показників виживаності протягом 5 та 10 років та раннього виявлення, яке проявлялося в зміні співвідношень стадій РРП, але, на жаль, не було суттєвого поліпшення показників смертності. Проте серед осіб, які брали участь у всіх 4 циклах скринінгу, виявляли зниження рівня смертності на $79 \%$ (показник 17,1 на 100000 знизився до 3,0 ) і $81 \%$ серед груп високого ризику (з 39 до 7,1). Це зниження смертності було значним. Однак важливо зазначити, що лише 19288 осіб пройшли всі 4 раунди скринінгу, що становить $20 \%$ популяції, що брала участь у проекті загалом [43, 44].

ПЗС, такі як еритроплакія та лейкоплакія, хоча згідно зі статистичними даними і мають вищий ризик малігнізації, можуть не прогресувати, або ж взагалі регресувати з часом. На сьогодні прогностичне значення уражень важко визначити, i жоден з наявних гістологічних або молекулярних маркерів не $є$ прогностично значущим. Незважаючи на це, дослідження продемонструвало відносно непоганіпоказники проведеної роботи. Проте розроблені методики не були затверджені на державному рівні ні в країні, де проводилося це спостереження, ні в інших державах світу.

З метою оцінки ефективності скринінгу РРП S. Warnakulasuriya та співавтори вивчили можливості скринінгу РРП, використовуючи тільки оцінку фізикального обстеження ротової порожнини (ФОРП). Крім вищеописаного, автори вивчили інші дослідження, які використовували ФОРП для виявлення відповідних уражень, але жодне зних не було рандомізованим контрольованим, 9 досліджень були лише описовими, тому обгрунтованість даних не могла бути оцінена. У цілому ці дослідження та висновок авторів вказують на те, що ФОРП має задовільний результат у випробуваннях з чутливістю та специфічністю, інколи подібний до тих, що описані в програмах скринінгу на рак молочної залози та шийки матки. Окрім того, у ряді цих досліджень брали участь не медичні працівники, і вони показували аналогічні результати здослідженнями, які виконували висококваліфікованіпрацівники. Це вказує на те, що працівники, які пройшли спеціальне навчання, та кваліфіковані стоматологічні фахівці однаково здатні провести ФОРП і виявити відповідні ураження, завдяки чому є можливість знизити собівартість методики [29, 31, 55, 57].

У ході більшої частини досліджень, які розглянули S. Warnakulasuriya та співавтори, вивчали наявність уражень, що відповідають ПЗС або РРП як критерію позитивного скринінгу. У більшості випадків це були зміни забарвлення слизової оболонки в білий або червоний колір чи різного типу виразки. Лейкоплакія виявилася найбільш поширеним ПЗС, іхочаії прояви були визначені з поширеністю від 1,4 до 22\%, важливо розуміти, що близько 95\% виявлених пошкоджень не є цінними для скринінгового тесту, оскільки лише близько 5\% лейкоплакій можуть перейти в РРП. Іншою важливою проблемою є об'єктивність даних, адже одні й ті ж клінічні ознаки, навіть за наявності чітких критеріїв оцінювання, можуть бути по різному трактовані різними членами скринінгових груп. Також відсутність фіксаціїданих унеможливлює ретроспективний аналіз методу, який би в подальшому дозволив удосконалити критерії оцінки та протоколи огляду [15, $16,21,38]$. Згодом у Кокрейнівському систематичному огляді, метою якого також була оцінка ефективності скринінгових програм РРП, було визнано значні позитивні результати досліджень в Кералі, але рецензенти виявили ряд методологічних недоліків, які впливають на обгрунтованість результатів. Також було визнано недостатність доказів для рекомендації існуючих методологічних підходів до проведення організованої скринінгової програми для всієї популяції. Проте вчені визнали, що такий метод скринінгу може знизити рівень смертності серед споживачів тютюну та алкоголю і призвести до так званого зсуву стадій РРП [4, 11, 33, 53, 54].

У ході аналізу було вивчено зв'язок між зміною стадійності процесу РРП і вживанням алкоголюі тютюну та виявлено, що вживання тютюну в будь-якій формі (жування або паління) вважається одним з основних факторів ризику РРП. Існує пряма залежність між щоденною дозою та тривалістю вживання тютюну і частотою виникнення РРП. Курці, які почали палити в молодшому віці, більш схильні до захворювання на РРП $[19,32]$. 
У доповіді американської служби охорони здоров’я (United States Department of Health and Human Services) було чітко визнано прямий причинний зв'язок між курінням і РРП. Американська асоціація раку спонсорувала 2 дослідження із запобігання раку (Cancer Prevention Study I та II). Згідно з даними Американського фонду раку ротової порожнини (The Oral Cancer Foundation) вони $€$ найбільшими епідеміологічними дослідженнями у світі, у кожному з них брали участь більше 1 млн чоловіків та жінок. Отримані дані показали, що ризик смерті від РРП у курців чоловічої статі в 27,7 раза вищий порівняно з некурцями, у осіб жіночої статі цей показник лише в 6 разів вищий. Ризик виникнення РРП у курців різко знижується після припинення тютюнопаління, після 5 років ризики знижується на 50\%, а через 10 років цей рівень відповідає аналогічному показнику серед осіб без цієї шкідливої звички [5].

Відповідно до даних досліджень А. Rodgman та співавторів тютюновий дим містить більше 4000 хімічних речовин, включаючи принаймні 70 відомих канцерогенів (хімічних речовин, що викликають, ініціюють або спричиняють розвиток раку). Відповідно до даних міністерства охорони здоров'я та соціальних служб США (United States Department of Health and Human Services HHS), багато з цих хімічних речовин потрапляють до організму людини і під час пасивного куріння. Бензоли є одними з багатьох хімічних речовин, що містяться в тютюновому димі. Ці органічні хімічні сполуки були визнані токсичними відповідно до Закону про захист навколишнього середовища Канади та Міжнародним агентством з дослідження раку (International Agency for Research on Cancer - IARC) класифіковані як канцерогени для людини. Тютюн містить і безліч інших канцерогенних молекул, особливо небезпечними визнані поліциклічні вуглеводні і нітрозаміни. Існують також канцерогени в тютюновому димі, які потребують метаболічної активації, такі ензими, як глутатіон-S-трансфераза, $\mathrm{N}$-ацетилтрансфераза та цитохром P450, відіграють важливу роль у канцерогенезі. Так, поліморфізм генів цих ферментів впливає на індивідуальний ризик виникнення РРП [41, 46].

Можливий фактор ризику розвитку РРП - алкоголь, виявився загалом каталізатором будь-якого канцерогенезу. Проте механізм його канцерогенної дії щодо РРП до кінця не встановлено. Наразі доведено, шо алкоголь здатний збільшити проникнення інших канцерогенів через слизову оболонку, діючи як розчинник. Також відомо, що потужним канцерогеном є перший метаболіт алкоголю - ацетальдегід, а чинники, що призводять до накопичення ацетальдегіду (зокрема збільшення конверсії алкоголю до ацетальдегіду та зниження його метаболічного перетворення до ацетату), можуть призвести до розвитку раку. Цікавим є факт виявлення N. Homann та групою співавторів накопичення ацетальдегіду в слині пацієнтів після посилення окиснення етанолу внаслідок активності мікрофлори порожнини рота, що пов'язують з підвищенням ризику розвитку РРП. Усе вищеперераховане підтверджується тим, що похідні ацетальдегідів були виявлені в тканинах ротової порожнини у пацієнтів з РРП та з передраковими станами [14, 30, 32, 56].

Іншим імовірним поясненням впливу алкоголю на канцерогенез, висунутим Н. Маiеr та співавторами, є зміна метаболічної активності печінки через хронічне вживання алкоголю, що призводить до активації канцерогенів, а також викликає зміну метаболізму ретиноїдів. Алкоголь також може призвести до дегенерації вегетативної іннервації та жирової інфільтрації слинних залоз, що призводить до зменшення слиновиділення. Це може призвести до накопичення канцерогенних речовин на поверхні слизової оболонки порожнини рота, що, у свою чергу, підвищує ризик РРП. Окрім цього, алкогольні напої можуть містити багато різних канцерогенних речовин, отриманих внаслідок бродіння, забруднення та використання добавок та ароматизаторів [1, 28]

Отже, дослідження показують, що ризик канцерогенезу зростає зі збільшенням кількості алкоголю, і цей факт пов'язаний не з типом напоїв, а із загальним вмістом алкоголю в них. Щоденне споживання близько 50 г алкоголю підвищує ризик виникнення раку порожнини рота, глотки, гортані та стравоходу в 2-3 рази порівняно із цим показником у людей, які не вживають спиртні напої [1, 19].
Загалом аналіз цих 2 чинників показав, що алкоголь і тютюн мають синергічний ефект в етіології РРП, проте і в осіб, що не палять, алкоголь $€$ потужним фактором ризику розвитку цієї патології. Ці шкідливі звички можуть виступати в якості критеріїв відбору населення і подальшого формування груп ризику для проведення опортуністичних скринінгових програм [10].

Опортуністичні спроби скринінгу відмічаються в літературі частіше, а в деяких країнах навіть існують протоколи та рекомендаціїдержавних органів охорони здоров'я. Відповідно до цих документів лікар, консультуючи пацієнта, який входить до групи ризику, зобов'язаний провести дослідження для спростування ризику виникнення або наявності злоякісного стану. Опортуністична програма скринінгу може проводитися за певним встановленим протоколом, за яким лікар проводить чітко визначені фізикальні дослідження, використовуючи різні інструментальні та лабораторні методи, для підтвердження або спростування ризику розвитку того чи іншого захворювання.

K. Lim та співавтори з метою визначення доцільності опортуністичного скринінгу РРП і ПЗС та для визначення поширеності у відповідних групах ризику провели проспективне демонстраційне дослідження, у якому взяли участь 18 кваліфікованих стоматологів, які пройшли спеціально розроблені підготовчі курси. Також вченими було розроблено чіткий протокол для оцінки ФОРП та критерії, за яких дослідження отримали позитивну або негативну оцінку. До огляду запрошували пацієнтів віком старше 35 років, які заповнювали спеціальні анкети, у яких були зазначені дані шодо вживання алкоголю та тютюну. Після анкетування стоматологами проводилося ФОРП. Автори отримали дані 2265 пацієнтів для аналізу, у $319(14,1 \%)$ були виявлені пошкодження слизової оболонки рота та язика, з них 94 (4,2\%) були визначені як позитивні (виявлена підозра на онкопроцес). Вченими було встановлено значний зв'язок між пошкодженнями та ступенем вживання тютюну серед осіб чоловічої статі. Узагальнюючи, автори дійшли висновку, що опортуністичний скринінг серед груп ризику може мати більш позитивний результат та нижчу собівартість, ніж загальні організовані скринінгові програми [21].

Для рентабельності, економії часу та досягнення мети опортуністичного скринінгу потрібно чітко розуміти фактори ризику та соціальні групи, у яких відмічають найвищий ризик виникнення РРП. Таким чином, Давід Конвай зі співавторами для оцінки впливу рівня якості життя на частоту виникнення РРП провели метааналіз та проаналізували 1648 робіт, у яких вивчали фактори ризику РРП. Результати показали, що більша частка досліджень - це праці, у яких соціально-економічні фактори ігноруються, натомість чимало досліджень спрямовані на вивчення асоціації РРП тільки зі шкідливими звичками та способом життя («lifestyle choices»), без урахування соціальних умов. Дослідження, у ході яких вивчали соціально-економічні фактори при оцінці ризику розвитку РРП, показали, що низький рівень освіти, побутових умов та соціально-економічний рівень країни асоціюються з високими показниками захворюваності на РРП. Таким чином, зроблено висновок, що саме ці соціальні групи населення мають бути цільовими в таргетованих опортуністичних скринінгових програмах, як у низько-, так і у високорозвинених країнах [35].

S. Langevin $з$ групою співавторів провели дослідження, метою якого було визначення зв'язку між частотою відвідування стоматолога та стадіями, на яких виявлено РРП. Вчені провели ретроспективний аналіз даних 441 хворого з різними стадіями РРП та раку ротоглотки, проаналізувавши частоту їх візитів до стоматолога. Автори визначили, що у пацієнтів, які рідко або ніколи не відвідували стоматолога, були виставлені більш пізні стадії РРП порівняно з хворими, які відвідували цього спеціаліста щорічно або й частіше. Вчені дійшли висновку, що регулярні профілактичні огляди стоматолога можуть призвести до значного «зсуву стадій» РРП, що призвело б до зниження смертності внаслідок цієї патології [20].

Крім цих факторів ризику, було проаналізовано численні дослідження, уході яких вивчали ВПЛ та його життєдіяльність 
у тканинах порожнини рота. Так, ДНК ВПЛ виявлено у близько 25\% випадків РРП. Деякі дослідження показують, що інфекція ВПЛ, особливо типу ВПЛ 16 та ВПЛ 18, що вважаються онкогенними, відіграє важливу роль у виникненні РРП. Механізм інфікування ВПЛ, особливо в порожнині рота, вивчений недостатньо. R. Herrero та співавтори у своїх дослідженнях припускають можливість передачі вірусу статевим шляхом, на що вказує виявлена ДНК ВПЛу біоптатах тканин ротової порожнини пацієнтів з РРП, які практикували оральний секс. Проте в дослідженнях J. Lissowska та співавторів не виявлено кореляції між оральним сексом та РРП. Хоча існує імовірність що вірус має можливість до транслокації всередині організму, цей факт до кінця залишається не вивченим і не використовується як критерій відбору пацієнтів для опортуністичних скринінгових програм [13, 23, 26].

Проте інше дослідження J. Lissowska та співавторів показало, що наявність хронічного болю, пов'язаного з неякісними зубними протезами чи такими, що вийшли з ладу чи/та у яких закінчився термін експлуатації, або гострими зубами, є фактором ризику розвитку РРП. Цей показник є значним навіть після коригування з урахуванням вживання тютюну та алкоголю. Проте опортуністичних скринінгових програм, які б враховували цей фактор, у ході аналізу не виявлено [23].

Крім вищеперерахованих факторів ризику, існують й інші фізичні чинники, такі якекспозиція ультрафіолетовим випромінюванням, щоє однією зпричин виникнення раку губи (якіпри інших онкологічних процесах шкіри). Таким чином, у осіб, які займаються такими видами діяльності, як сільське господарство, риболовля або поштова служба, відмічають більш високий ризик [25]. Іншим фізичним чинником виступають рентгенівські промені. Рентгенографія під час досліджень $є$ відносно безпечною, але не варто забувати, що радіоактивна експозиція має здатність до акумуляції.

Зв'язок міждієтою та раком порожнини рота вже тривалий час є предметом дискусій. У ряді досліджень К. Steinmetz та J. Potter було встановлено та кількісно визначено позитивний ефект дієт, багатих на фрукти та овочі. Аналіз Національного інституту раку СШАпоказав зниження на 28\% ризику виникнення РРП при вживанні 50 г овочів без крохмалю і 50 г цитрусових плодів [47, 60].

У дослідженні P. Balaram та співавторів було визначено роль недостатньої гігієни порожнини рота (низька частота чищення та/або погана стоматологія) у канцерогенезі навіть після коригування даних з урахуванням вживання тютюну та алкоголю [2]. A. Velly та співавторами також було виявлено зворотній зв'язок між частотою чищення зубів та виникненням РРП. Дослідження N. Homann та співавторів також показали вищий рівень ацетальдегіду в слині тих, хто курить і вживає алкоголь, за недостатньої гігієни порожнини рота $[13,14,51]$.

Підвищення частоти РРП виявляють у осіб зі зниженим імунітетом, це показали у своїх дослідженнях E. Lopez та співавтори, у декількох пацієнтів після трансплантації нирок, на фоні імуносупресивної терапії, а також у молодих пацієнтів з ВІЛ була зареєстрована висока частота РРП [25].

Генетична схильність вважається фактором ризику для всіх видів онкопроцесів. Дослідження Т. Sreelekha та співавторів показали, що у осіб з поліморфізмом в GSTM1 та CYP1A1 відмічають генетично підвищений ризик розвитку раку порожнини рота, особливо цей рівень високий у курців. Інші генетичні зміни спостерігалися у пацієнтів з РРП, включаючи активацію протоонкогенів, таких як циклін D1, RAS, MYC, EGFR, та інактивацію генів супресорів пухлини [46].

Усі ці суперечливі моменти потребують подальшого вивчення, оскільки всі вищеперераховані фактори ризику можуть стати новими критеріями для відбору до участі в опортуністичних програмах. Також чітке розуміння етіології РРП дозволяє впровадити інноваційні методи, які можуть дати новий поштовх скринінгу РРП.

Аналіз літературних джерел показав, що основним методом як в організованих, так і в опортуністичних дослідженнях було використання ФОРП. В різних дослідженнях використовували різні протоколи, підходи та критерії оцінки стану ротової порожнини. Отже, загального сформульованого протоколу або чітких критеріїв
Таблиця 1. Класифікація методик для ранньої діагностики РРП

\begin{tabular}{|c|c|}
\hline Прижиттєве тка- & 5\% оцтовим розчином \\
\hline нинне забарв- & Толуїдиновим синім \\
\hline лення & Метиленовим синім \\
\hline & Розчином Люголя \\
\hline & Роз-бенгал \\
\hline & Фарбування йодом \\
\hline & Толоніум хлорид \\
\hline $\begin{array}{l}\text { Світлові діагнос- } \\
\text { тичні системи }\end{array}$ & $\begin{array}{l}\text { Тканина флуоресцентна візуалізація (Velscope, } \\
\text { identafi 3000) }\end{array}$ \\
\hline & Хемілюмінесценція (ViziLite plus, Microlux/DL) \\
\hline & Тканинна флуоресцентна спектроскопія (NBI) \\
\hline Гістологічні ме- & Інцизійна біопсія \\
\hline тоди & Ексцизійна біопсія \\
\hline Цитологічні ме- & Біопсія зі щіткою (Oral CDX) \\
\hline тоди & Рідинна цитологія \\
\hline & Лазерне мікророзділення (LCMd) \\
\hline Молекулярні ме- & Генна альтерація \\
\hline тоди & $\begin{array}{l}\text { Епігенетична альтерація, втрата гетерозиготності } \\
\text { та мікросателітні нестабільності }\end{array}$ \\
\hline & Визначення вірусних ДНК \\
\hline & Індекс проліферації та аналіз AgNOR \\
\hline & Імуногістохімічна ідентифікація пухлинних маркерів \\
\hline $\begin{array}{l}\text { Візуалізаційні } \\
\text { методи }\end{array}$ & $\begin{array}{l}\text { Позитронно-емісійне сканування з використанням } \\
\text { фтордезоксиглюкози }\end{array}$ \\
\hline & Оптична когерентна томографія \\
\hline Інші методи & Onco-chips T \\
\hline
\end{tabular}

оцінки наразі не існує. 3 метою пошуку потенційно ефективних методів скринінгу РРП нами було розглянуто шляхи ранньої діагностики цієї патології, які б самостійно або в комплексі з ФОРП відповідали основним критеріям скринінгу.

Під час аналізу було виявлено, що існують різні допоміжні методики скринінгу чи виявлення РРП, які можна класифікувати у 7 груп (табл. 1). На кожному з них ми вирішили зупинитися і проаналізувати ефективність, точність, інвазивність та інші показники, що $€$ необхідними для успішності скринінгу.

Так, опрацьовано чимало досліджень, у яких ФОРП поєднували з іншими діагностичними ад'юнктами (допоміжними діагностичними методами). Для оцінки технік та методик, які використовуються для ранньої діагностики РРП, а також для оцінки сучасних тенденцій у цьому напрямку, C. Carreras-Torras та C. Gay-Escoda з Іспанії провели в 2015 р. систематичний огляд літератури. За встановленими критеріями автори відібрали для аналізу 60 статей (1 метааналіз, 17 систематичних оглядів, 35 проспективних досліджень, 5 ретроспективних досліджень, 1 консенсус та 1 напівструктуроване інтерв’ю). Автори визначили на момент проведення дослідження актуальні методи та техніки (див. табл. 1). Вчені дійшли висновку, що результати, отримані в ході аналізу відібраної літератури, є недостатніми для виділення окремих вагомих ад’ювантних методик, і визнають, що гістологічна оцінка біоптатів надалі залишається золотим стандартом [6].

Пізніше M.W. Lingen та співавтори в 2017 р. вивчили 4 систематичні огляди [22]. Серед отриманих 5734 записів у ході 9 досліджень вивчали точність діагностичного тесту і в 10 дослідженнях - цінність та перевагу для пацієнтів. Чутливість та специфічність додаткових методів у цих дослідженнях коливалися від 0,39 до 0,96 для оцінки непідозрілих уражень і від 0,31 до 0,95 - для оцінки підозрілих уражень. Цитологічний аналіз, який використовували під час виявлення підозрілих уражень, мав найвищу точність серед додаткових методів дослідження (чутливість 0,92; 95\% довірчий інтервал 0,86-0,98; специфічність 0,$94 ; 95 \%$ довірчий інтервал 0,88-0,99, низькоякісна доказовість). У ході дослідження вчені проаналізували отримані результати за кожним з методів, що вивчали у всіх відібраних дослідженнях, і виявили загальнонизький рівень доказовості у всіх діагностичних ад'юнктах [27].

За даними авторів, цитологічне тестування виявилося найбільш точним методом серед тих, що включені в їх огляд. Основними проблемами є висока частота хибнопозитивних результатів та непряма доказовість результатів. Автори рекомендували клініцистам залишатися скептичними щодо потенційної користі будь-якихдодаткових діагностичних методик в клінічній практиці. 
Принципово іншим допоміжним методом скринінгу РРП $€$ тканинне забарвлення. K. Bhalang та співавтори визначали чутливість та специфічність використання 5\% оцтового розчину в оцінці РРП. Дослідження включало 30 учасників, у яких була підозра на РРП. Після застосування розчину проводилася біопсія для аналізу результатів. Чутливість, специфічність і точність використання розчину оцтової кислоти були 83,33; 84,21 та 83,64\% відповідно. Автори дійшли висновку, що використання розчину оцтової кислоти має високу чутливість та специфічність в оцінці РРП в таргетованих групах [3].

Толонію хлорид, що частіше згадується як толуїдиновий синій (ТС), використовувався більше 40 років для виявлення аномалій слизової оболонки шийки матки та порожнини рота. TC - це метахроматичний барвник, який зв'язується переважно 3 клітинами, здатними до швидкого поділу (наприклад у запальних, регенеративних та неопластичних тканинах). Зв’язування призводить до забарвлення анормальної тканини. Метааналіз D. Rosenberg та S. Cretin підсумував 12 досліджень, проведених у період 1964-1984 рр., і виявив загальну чутливість 93,5\% та специфічність 73,3\% для цього методу [42].

Принцип фарбування при використанні розчину люголя полягає в тому, що клітини, які мають вищий вміст глікогену, утримують більше барвника, ніж ті, у яких він $є$ нижчим. Таким чином, тканини, задіяні в онкопроцесі, не фарбуються, і візуалізуються чіткі межі патологічного процесу. J. Epstein та співавтори провели оцінку чутливості та специфічності цього методу і отримали наступні показники - 87\% чутливості та 84\% специфічності [9].

Ефективність використання тесту роз-бенгала була оцінена в роботах G. Du та співавторів, у яких вони довели вищу ефективність використання цього тесту порівняно зі звичайним ФОРП (93,7 проти $72,7 \%)[8]$.

A. Watanabe зі співавторами перевірили ефективність фарбування йодом і отримали високу чутливість $-100 \%$ та відносно високу специфічність - 59,6\%. Авторами було запропоновано використання цього методу при хірургічному лікуванні для демаркації здорових ділянок тканин [58].

L. Patton та співавтори у своїх дослідженнях припустили, що толонію хлорид переважно фарбує ділянки тканини, у яких відбувається активний поділ. У свою чергу, D. Rosenberg з групою співавторів визначили чутливість і специфічність такого методу, ці показники становили 93,5 та 73,3\% відповідно [37, 38, 42].

Результати різних досліджень є досить суперечливими, що не дозволяє нам дійти консолідованого висновку з приводу методів тканинного забарвлення в контексті скринінгу РРП. Наукові дослідження в цьому напрямку тривають.

Щодо світлових методів скринінгу існує декілька прикладів візуалізаційних ад'юнктів, які призначені для використання уякості додатка до ФОРП. Ці методи використовують різноманітні лампи таджерела світла, вони працюють за принципом відбивання світла різної довжини. Завдяки тому що тканини слизової оболонки, які зазнають анормальних метаболічних або структурних змін, мають різні профілі поглинання та відбиття світла через різні візуалізаційні системи, можна визначити демаркаційні лінії та ділянки порушень цілісності слизової оболонки, які невидимі неозброєним оком.

Існує декілька комерційних продуктів, які використовуються в стоматологічній та хірургічній практиці.

Система VELscope - багатофункціональний ручний пристрій, через який лікар може візуально сканувати слизову оболонку та оцінювати зміни флуоресценції тканин. Запропонований механізм флуоресценціїтканин полягає в тому, що тканини слизової оболонки мають рефлексивний та абсорбційний характер на основі природних флюорофорів тканин. Флюоресценція тканин у ротовій порожнині варіабельна і на неї впливають структурні зміни, метаболічна активність, наявність гемоглобіну в тканині, розширення судин, запалення. Ця мінливість не визначена. Експозиція спектрів синього світла (400-460 нм) може максимізувати диференційний профіль у ділянках, що зазнають неопластичних змін, у яких визначається втрата флуоресценції.
VELscope виявився корисним тільки для оцінки ураження РРП і показував свою ефективність інтраопераційно, оскільки дозволяв хірургам визначити чіткі демаркаційні лінії. У жодному з опублікованих досліджень не було оцінено систему VELscope у групах з низьким ризиком або на рівні первинної медичної допомоги. Враховуючи мінливість флуоресценції слизової оболонки порожнини рота та високу поширеність доброякісних уражень, специфічність такого методу не $є$ високою [36].

Описаний як хемілюмінесцентна світлова система виявлення тканинних порушень ViziLite був розроблений шляхом модифікації предикатних пристроїв для виявлення неоплазії шийки матки. Після застосування оцтової кислоти ділянки проліфераціїепітелію, що містять клітини зі змінною ядерною структурою, переважно відбивали синьо-біле світло, яке випромінює пристрій. Система ViziLite більше не доступна як окремий продукт, але є частиною системи ViziLite Plus з системою TBlue, що використовує замість оцтової кислоти ТС.

L. Patton та співавтори провели метааналіз опублікованих досліджень, у яких використовувалася система ViziLite. Автори виявили, що приблизно в $60 \%$ порушень слизової оболонки система ViziLite сприяла підвищенню візуалізації, яка вказувала не лише на злоякісні ураження, а й на інші доброякісні процеси, тим самим знижуючи специфічність цього методу. Цідослідження проводилися в таргетованих відібраних групах, досліджень з використанням ViziLite у групах з низьким ступенем ризику не було виявлено [36].

Крім ViziLite та VELscope існують й інші світлові методи, такі як система Microlux DL та Orascoptic DK, проте їх ефективність не вивчена.

Microlux DL - це багатофункціональна система, розроблена 3 використанням синьо-білого світлодіоду (LED) та розсіяного волокно-оптичного світлодіодного пристрою, що створює синє світло з низькою енергією.

Система Orascoptic DK - це 3 індивідуальних світлодіодні інструменти з ручним приводом від батареї з прикріпленим інструментом для скринінгу ураження порожнини рота, який використовується в поєднанні з промиванням легкою оцтовою кислотою, що сприяє поліпшенню візуалізації змін тканин ротової порожнини.

Ще одним підходом до скринінгу РРП можуть бути цитологічні тести, які являють собою мікроскопічні дослідження клітинних зразків, зібраних з поверхні слизової оболонки (шляхом мазків, зскрібків чи лаважів) або з внутрішніх ділянок шляхом аспірації тонкою голкою.

Одним з прикладів використання цитологічних тестів для дослідження ротової порожнини є система OralCDx Brush Test, яка використовує спеціальну шіточку для забору трансепітеліальних клітинних зразків, що складаються з вільних клітин і кластерів. Ці зразки фіксуються на склі та направляються в лабораторію, де вони забарвлюються (з використанням модифікованого тесту Papanicolaou), скануються та аналізуються мікроскопічно за допомогою комп'ютерної системи, яка здатна оцінювати клітини за ступенем анормальності їх морфології. Результати визнаються як «негативні» (тобто доброякісні), «позитивні» або «нетипові».

K. Costa Fontes та співавтори вивчали ефективність цитологічних тестів в таргетованих групах пацієнтів та встановили, що чутливість таких методик становить $83,1 \%$, а специфічність - близько $100 \%$ [7]. Схожою є методика використання гістологічних досліджень. Наразі золотим стандартом діагностики РРП залишається гістологічна оцінка біоптатів, отриманих за допомогою інцизійної або ексцизійноїбіопсії, з використанням імуногістохімічних методів. Кожний із цих методів має свою особливість та специфіку, але при правильному виконанні здотриманням усіх вимог результати, отримані при біопсії, показують найвищі показники чутливості та специфічності. Єдиною можливою перешкодою цього методу є локалізація пухлин або ерозій, за яких ускладнюється доступ, що може спричиняти появу хибнонегативних результатів.

Хоча цей метод $€$ найкращим в діагностиці РРП, під час його використання як скринінгового методу в організованих програмах 
Оглядові статті / Review Articles

Таблиця 2. Критерії скринінгових програм NSC

\section{Стан нозології}

Захворювання має бути важливою проблемою для суспільства та економіки країни

Епідеміологія та патогенез захворювання (від асимптоматичної фази до пізніх стадій хвороби) повинні бути адекватно оціне-

ні та виявлені чіткі фактори ризику, маркери захворювання мають бути чітко зрозумілі на всіх стадіях захворювання

\section{Скринінговий тест}

Тест скринінгу має бути простим, безпечним, точним та перевіреним

Розподіл оцінювальних значень у цільовій популяції має бути відомим

\section{Лікування}

Має існувати ефективний метод лікуванням для пацієнтів, виявлених шляхом раннього скринінгу, з доказами того, що раннє лікування призводить до кращого результату, ніж у разі пізнього втручання

Має бути погоджена доказова політика, яка координує розподіл осіб, яким слід запропонувати лікування

Скринінгова програма

Мають бути докази високоякісних рандомізованих контрольованих досліджень, що скринінгова програма ефективна для зни-

ження захворюваності на відповідну патологію та смертності внаслідок неї

з'являється низка причин, такі як собівартість, складність у виконанні та неприємні відчуття пацієнтів.

Також за останні роки популярнішими для вивчення стали молекулярні маркери РРП. У 2018 р. з метою вивчення сучасних тенденцій та ефективності молекулярних тестів Цесар Рів’єра та співавтори провели систематичний огляд літератури і виявили 41 методику, більшість з яких полягали у виявленні специфічних білків за допомогою імуногістохімічних методів [40]. У результаті вчені дійшли висновку, шо ці тести є тільки потенційними біомаркерами, і наразі не існує достатньо доказів та рандомізованих досліджень для рекомендації використання цих методів у медичній практиці.

Усі ці методи виявилися корисними в якості допоміжних діагностичних засобів для скринінгу осіб з високим ступенем ризику в закладах вторинного рівня. Наразі не було виявлено жодних доказів використання цих методів як основних для скринінгових програм. Кокрейнівський систематичний огляд узагальнив, що жоден з методів, що були додатковими до ФОРП, не можна рекомендувати як заміну поточного діагностичного стандарту (пункційної біопсії та гістологічної оцінки біоптату) [27].

\section{ВИСНОВКИ}

Загалом аналіз літературних джерел показав, що наразі не існує ефективних методів скринінгу РРП, які б були водночас високоточними, високоефективними, рентабельними та задовольняли б усі інші вимоги до скринінгу.

Натомість дані про РРП та відповідні програми скринінгу задовольняють не більше 2 критеріїв 37 (табл. 2).

Наразі найбільшою перешкодою для створення та впровадження скринінгу є нерозуміння етіології, факторів ризику та патогенезу РРП на ранніх стадіях, навіть у розвинутих країнах світу, де фінансове забезпечення цих програм є можливим.

При цьому, незважаючи на нагальність питання раннього виявлення та скринінгу РРП, методи скринінгу, що існують на сьогодні, не є точними та інформативними, а державні скринінгові програми для виявлення РРП взагалі відсутні у світі. Досі всі спроби створення програм для скринінгу РРП виявилися неуспішними, а на державному рівні таких програм не існує зовсім. У контексті стійкої тенденції до зростання захворюваності на РРП впродовж останніх років вищевказане зумовлює високу потребу у розробці скринінгових програм, необхідність пошуку точних методів скринінгу РРП та актуальність глибшого дослідження цієї теми.

\section{СПИСОК ВИКОРИСТАНОЇ ЛІТЕРАТУРИ}

1. Baan, R., Straif, K., Grosse, Y., Secretan, B., El Ghissassi, F., Bouvard, V., ...Cogliano, V. (2007). Carcinogenicity of alcoholic beverages. The Lancet Oncology, 8, 292-293. doi: 10.1016/s1470-2045(07)70099-2

2. Balaram, P., Sridhar, H., Rajkumar, T., Vaccarella, S., Herrero, R., Nandakumar, A., ..Gajalakshmi, V. (2002). Oral cancer in southern India: The influence of smoking, drinking, paan-chewing and oral hygiene. International Journal of Cancer, 98, 440-445. doi: $10.1002 /$ ijc. 10200

3. Bhalang, K., Suesuwan, A., Dhanuthai, K., Sannikorn, P., Luangjarmekorn, L., \& Swasdison, S. (2008). The application of acetic acid in the detection of oral squamous cell carcinoma. Oral Surgery, Oral Medicine, Oral Pathology, Oral Radiology, and Endodontology, 106, 371-376. doi: 10.1016/j.tripleo.2008.01.017

4. Brocklehurst, P., Kujan, O., O'Malley, L. A., Ogden, G., Shepherd, S., \& Glenny, A. (2013). Screening programmes for the early detection and prevention of oral cancer. Cochrane database of systematic reviews. doi: 10.1002/14651858.cd004150.pub3
5. Cancer Prevention Study II (CPS II), American Cancer Society. Retrieved from https://www.cancer.org/research /we-conduct-cancer-research /epidemiology/ cancer-prevention-study-2.html

6. Carreras-Torras, C., \& Gay-Escoda, C. (2015). Techniques for early diagnosis of oral squamous cell carcinoma: Systematic review. Medicina Oral, Patologia Oral y Cirugia Bucal, 20, 305. doi: $10.4317 /$ medoral. 20347

7. Costa Fontes, K. B. F., Cunha, K. S. G., Rodrigues, F. R., Silva, L. E., \& Dias, E. P. (2013). Concordance between cytopathologyand incisional biopsyin the diagnosis of oral squamous cell carcinoma. Brazilian Oral Research, 27, 122-127. doi: 10.1590/s1806-83242013000100018

8. Du, G., Li, C., Chen, H., Chen, X., Xiao, Q., Cao, Z., ...Cai, X. (2007). Rose bengal staining in detection of oral precancerous and malignant lesions with colorimetric evaluation: a pilot study. International Journal of Cancer, 120, 1958-1963 doi: 10.1002/ijc.22467

9. Epstein, J. B., Scully, C., \& Spinelli, J. (1992). Toluidine blue and Lugol's iodine application in the assessment of oral malignant disease and lesions at risk of malignancy. Journal of Oral Pathology \& Medicine, 21, 160-163. doi: 10.1111/j.1600-0714.1992.tb00094.x 10. Franceschi, S., Talamini, R., Barra, S., Baron, A. E., Negri, E., Bidoli, E., La Vecchia, C. (1990). Smoking and drinking in relation to cancers of the oral cavity, pharynx, larynx, and esophagus in northern Italy. Cancer Research, 50, 6502-6507.

11. Gale, N., Pilch, B. Z., Sidransky, D., El-Naggar, A. K., Westra, W., \& Califano, J. (2005). Tumours of the oral cavity and oropharynx (Epithelial precursor lesions). World Health Organization classification of tumours. Pathology and genetics of head and neck tumours. Lyon: International Agency for Research on Cancer, 177-179.

12. Greenberg, J. S., Fowler, R., Gomez, J., Mo, V., Roberts, D., El Naggar, A. K., \& Myers, J. N. (2003). Extent of extracapsular spread: a critical prognosticator in oral tongue cancer. Cancer: Interdisciplinary International Journal of the American Cancer Society, 97 1464-1470. doi: $10.1002 /$ cncr. 11202

13. Herrero, R., Castellsagu?, X., Pawlita, M., Lissowska, J., Kee, F., Balaram, P. ...Pintos, J. (2003). Human papillomavirus and oral cancer: the International Agency for Research on Cancer multicenter study. Journal of the National Cancer Institute, 95, 1772 1783. doi: $10.1093 /$ jnci/djg107

14. Homann, N., Jousimies-Somer, H., Jokelainen, K., Heine, R., \& Salaspuro, M. (1997). High acetaldehyde levels in saliva after ethanol consumption methodological aspects and pathogenetic implications. Carcinogenesis, 18, 1739-1743. doi: 10.1093/carcin/18.9.1739.

15. Ikeda, N., Downer, M. C., Ishii, T., Fukano, H., Nagao, T., \& Inoue, K. (1995). Annual screening for oral cancer and precancer by invitation to 60 -year-old residents of a city in Japan. Community dental health, 12, 133-137.

16. Jullien, J. A., Downer, M. C., Zakrzewska, J. M., \& Speight, P. M. (1995). Evaluation of a screening test for the early detection of oral cancer and precancer. Community Dental Health, 12,7 .

17. Kazmi, F., Chaudhary, M. A., Mumtaz, M., Bhatti, M. U. D., \& Khawaja, N. (2011). Oral cancer knowledge and awareness amongst undergraduate dental students of LahorePakistan. Pakistan Oral and Dental Journal, 31(1), 64-67.

18. Kim, S. M. (2016). Human papilloma virus in oral cancer. Journal of the Korean Association of Oral and Maxillofacial Surgeons, 42, 327-336.

19. La Vecchia, C., Tavani, A., Franceschi, S., Levi, F., Corrao, G., \& Negri, E. (1997). Epidemiology and prevention of oral cancer. Oral Oncology, 33, 302-312. doi: 10.1016/s0964-1955(97)00029-8

20. Langevin, S. M., Michaud, D. S., Eliot, M., Peters, E. S., McClean, M. D., \& Kelsey, K. T. (2012). Regular dental visits are associated with earlier stage at diagnosis for oral and pharyngeal cancer. Cancer Causes \& Control, 23, 1821-1829. doi: 10.1007/s10552-012-0061-4

21. Lim, K., Moles, D. R., Downer, M. C. \& Speight, P. M. (2003). Opportunistic screening for oral cancer and precancer in general dental practice: results of a demonstration study. British Dental Journal, 194, 497. doi:10.1038/sj.bdj.4810069

22. Lingen, M. W., Tampi, M. P., Urquhart, O., Abt, E., Agrawal, N., Chaturvedi, A. K., Kerr, A. R. (2017). Adjuncts for the evaluation of potentially malignant disorders in the oral cavity: diagnostic testaccuracy systematic reviewand meta-analysis - a report of the American Dental Association. The Journal of the American Dental Association, 148(11), 797-813. doi: 10.1016/j.adaj.2017.08.045

23. Lissowska, J., Pilarska, A., Pilarski, P., Samolczyk-Wanyura, D., Piekarczyk, J., Bardin-Mikollajczak, A., ...Franceschi, S. (2003). Smoking, alcohol, diet, dentition and sexual practices in the epidemiology of oral cancer in Poland. European Journal of Cancer Prevention, 12, 25-33. doi: 10.1097/00008469-200302000-00005

24. Llewellyn, C. D., Johnson, N. W., \& Warnakulasuriya, K. (2001). Risk factors for squamous cell carcinoma of the oral cavity in young people - a comprehensive literature review. Oral Oncology, 37, 401-418. doi: 10.1016/s1368-8375(00)00135-4

25. Lopez, E. P., Minarro-Del Moral, R. M., Martinez-Garcia, C., Zanetti, R., Rosso, S., Serrano, S., ...Redondo, M. (2003). Lifestyles, environmental and phenotypic factors associated with lip cancer: a case-control study in southern Spain. British Journal of Cancer, 88, 1702. doi: $10.1038 /$ sj.bjc. 6600975

26. Luo, C., Roan, C., \& Liu, C. (2007). Human papillomaviruses in oral squamous cell carcinoma and pre-cancerous lesions detected by PCR-based gene-chip array. International Journal of Oral and Maxillofacial Surgery, 36, 153-158. doi: 10.1016/.j.jom.2006.09.005

27. Macey, R., Walsh, T., Brocklehurst, P., Kerr, A. R., Liu, J. L., \& Lingen, M. W. (2015). Diagnostic tests for oral cancer and potentially malignant disorders in patients presenting with clinically evident lesions. Cochrane Database Syst Rev, 29(5), CD010276. doi: 10.1002/14651858.CD010276.pub2 
28. Maier, H., Dietz, A., Gewelke, U., Seitz, H. K., \& Heller, W. D. (1990). Tobacco-and alcohol-associated cancer risk of the upper respiratory and digestive tract. Laryngo-rhinootologie, $69,505-511$.

29. Mathew, B., Sankaranarayanan, R., Sunilkumar, K. B., Kuruvila, B., Pisani, P., \& Nair, M. K. (1997). Reproducibility and validity of oral visual inspection by trained health workers in the detection of oral precancer and cancer. British Journal of Cancer, 76, 390. doi: 10.1038/bjc. 1997.396

30. Matsuo, K., Hamajima, N., Shinoda, M., Hatooka, S., Inoue, M., Takezaki, T., \& Tajima, K. (2001). Gene-environmentinteraction between an aldehyde dehydrogenase-2 (ALDH2) polymorphism and alcohol consumption for the risk of esophageal cancer. Carcinogenesis, 22, 913-916. doi: 10.1093/carcin/22.6.913

31. Mehta, F. S., Gupta, P. C., Bhonsle, R. B., Murti, P. R., Daftary, D. K., \& Pindborg, J. J. (1986). Detection of oral cancer using basic health workers in an area of high oral cance incidence in India. Cancer Detect Prev, 9, 219-25.

32. Muwonge, R., Ramadas, K., Sankila, R., Thara, S., Thomas, G., Vinoda, J., \& Sankaranarayanan, R. (2008). Role of tobacco smoking, chewing and alcohol drinking in the risk of oral cancer in Trivandrum, India: a nested case-control design using incident cancer cases. Oral Oncology, 44, 446-454. doi: 10.1016/j.oraloncology.2007.06.002

33. Napier, S. S., \& Speight, P. M. (2008). Natural history of potentially malignant ora lesions and conditions: an overview of the literature. Journal of Oral Pathology \& Medicine 37, 10. doi: $10.1111 / \mathrm{j} .1600-0714.2007 .00579 . x$

34. National Institute of Dental and Craniofacial Research. From https://www.nidcr.nih.gov/ research/data-statistics/oral-cancer/survival-rates

35. McCormick, M.C., Almario, D.A., \& Stoto, M.A. (1999). Reducing the odds: preventing perinatal transmission of HIV in the United States. National Academies Press. doi: $10.17226 / 6307$

36. Patton, L. L., Epstein, J. B., \& Kerr, A. R. (2008). Adjunctive techniques for oral cancer examination and lesion diagnosis: a systematic review of the literature. The Journa of the American Dental Association, 139, 896-905. doi: 10.14219/jada.archive.2008.0276.

37. Patton, L. L., \& Shugars, D. C. (1997). Detecting, diagnosing, and preventing oral cancer. Nurse Pract, 22(6), 105, 109-10.

38. Petti, S. (2003). Pooled estimate of world leukoplakia prevalence: a systematic review. Oral Oncology, 39, 770-780. doi: 10.1016/s1368-8375(03)00102-7

39. Ramadas, K., Sankaranarayanan, R., Jacob, B. J., Thomas, G., Somanathan, T., Mahe, C., ...Mathew, B. (2003). Interim results from a cluster randomized controlled oral cancer screening trial in Kerala, India. Oral Oncology, 39, 580-588. doi: 10.1016/s1368-8375(03)00041-1

40. Rivera, C., Oliveira, A. K., Costa, R. A. P., De Rossi, T., \& Leme, A. F. P. (2017). Prognostic biomarkers in oral squamous cell carcinoma: a systematic review. Oral Oncology, 72 , 38-47. doi: 10.1016/j.oraloncology.2017.07.003

41. Rodgman, A., \& Perfetti, T. A. (2016). The chemical components of tobacco and tobacco smoke. CRC Press. doi: 10.1201/9781420078848

42. Rosenberg, D., \& Cretin, S. (1989). Use of meta-analysis to evaluate tolonium chloride in oral cancer screening. Oral Surgery, Oral Medicine, Oral Pathology, 67, 621-627. doi: 10.1016/0030-4220(89)90286-7

43. Sankaranarayanan, R., Ramadas, K., Thara, S., Muwonge, R., Thomas, G., Anju, G., \& Mathew, B. (2013). Long term effect of visual screening on oral cancer incidence and mortality in a randomized trial in Kerala, India. Oral Oncology, 49, 314-321. doi: 10.1016/j.oraloncology.2012.11.004

44. Sankaranarayanan, R., Ramadas, K., Thomas, G., Muwonge, R., Thara, S., \& Mathew, B. (2005). Effect of screening on oral cancer mortality in Kerala, India: a cluster-randomised controlled trial. The Lancet, 365, 1927-1933. doi: 10.1016/s0140-6736(05)66658-5

45. Snow, G. B., Van den Brekel, M., Leemans, C. R., \& Patel, P. (1994). Surgical management of cervical lymph nodes in patients with oral and oropharyngeal cancer. Carcinoma of the Oral Cavity and Oropharynx, 43, 55. doi: 10.1007/978-3-642-84971-8_6

46. Sreelekha, T. T., Ramadas, K., Pandey, M., Thomas, G., Nalinakumari, K. R., \& Pillai, M. R. (2001). Genetic polymorphism of CYP1A1, GSTM1 and GSTT1 genes in Indian ora cancer. Oral Oncology, 37, 593-598. doi: 10.1016/s1368-8375(01)00028-8

47. Steinmetz, K. A., \& Potter, J. D. (1991). Vegetables, fruit, and cancer. I. Epidemiology. Cancer Causes \& Control, 2, 325-357. doi: 10.1007/bf00051672

48. Subramanian, S., Sankaranarayanan, R., Bapat, B., Somanathan, T., Thomas, G. Mathew, B., ...Ramadas, K. (2009). Cost-effectiveness of oral cancer screening: results from a cluster randomized controlled trial in India. Bull World Health Organ, 87(3), 200-206. doi: $10.2471 /$ blt.08.053231

49. The Oral Cancer Foundation. From https://oralcancerfoundation.org/screening/

50. Timar, J., Csuka, O., Remenar, E., Repassy, G., \& Kasler, M. (2005). Progression of head and neck squamous cell cancer. Cancer and Metastasis Reviews, 24(1), 107-127. doi: 10.1007/s10555-005-5051-5

51. Velly, A. M., Franco, E. L., Schlecht, N., Pintos, J., Kowalski, L. P., Oliveira, B. V. d., \& Curado, M. P. (1998). Relationship between dental factors and risk of upper aerodigestive tract cancer. Oral Oncology, 34, 284-291. doi: 10.1016/s1368-8375(98)00003-7

52. Vessecchia, G., Di Palma, S., \& Giardini, R. (1995). Submandibular gland metastasis of breast carcinoma: a case report and review of the literature. Virchows Archiv, 427, 349-351. doi: $10.1007 /$ bf00203404

53. Warnakulasuriya, S. (2000). Lack of molecular markers to predict malignant potential of oral precancer. The Journal of Pathology. A Journal of the Pathological Society of Great Britain and Ireland, 190, 407-409. doi: 10.1002/(sici)1096-9896 (200003) 190:4<407::aid-path546>3.0.co;2-d

54. Warnakulasuriya, S., Johnson, N. W., \& Van der Waal, I. (2007). Nomenclature and classification of potentially malignant disorders of the oral mucosa. Journal of oral pathology \& medicine, 36,575-580. doi: 10.1111/j.1600-0714.2007.00582.x

55. Warnakulasuriya, S., Fennell, N., Diz, P., Seoane, J., \& Rapidis, A. (2015). An appraisa of oral cancer and pre-cancer screening programmes in Europe: a systematic review. Journa of Oral Pathology \& Medicine, 44, 559-570. doi: 10.1111/jop.12267

56. Warnakulasuriya, S., Parkkila, S., Nagao, T., Preedy, V. R., Pasanen, M., Koivisto, H., \& Niemela, O. (2008). Demonstration of ethanol-induced protein adducts in ora leukoplakia (pre-cancer) and cancer. Journal of Oral Pathology \& Medicine, 37, 157-165. doi: 10.1111/j. 1600-0714.2007.00605.x

57. Warnakulasuriya, S., \& Pindborg, J. J. (1990). Reliability of oral precancer screening by primary health care workers in Sri Lanka. Community Dental Health, 7, 73-79.

58. Watanabe, A., Taniguchi, M., Tsujie, H., Hosokawa, M., Fujita, M., \& Sasaki, S. (2012). Clinical impact of iodine staining for diagnosis of carcinoma in situ in the floo of mouth, and decision of adequate surgical margin. Auris Nasus Larynx, 39, 193-197. doi: 10.1016/j.anl.2011.08.004

59. Wilson, J. M. G., \& Jungner, G. (1968). Principles and practice of screening for disease. The Journal of the Royal College of General Practitioners, 16(4), 318.

60. World Cancer Research Fund International. Retrieved from https://www.wcrf.org/ dietandcancer
61. Федоренко, З. П., Михайлович, Ю. Й., Гулак, Л. О., Горох, Є. Л., Рижов, А. Ю., Сумкіна, О. В., \& Куценко, Л. Б. (2018) Рак в Україні, 2016-2017. Захворюваність, смертність, показники діяльності онкологічної служби. Бюлетень Національного канцер-реєстру України, 19, 121. Retrieved from http://www.ncru.inf.ua/ publications/BULL 19/index.htm

62. Всесвітня організація з охорони здоров'я. Retrieved from http://screening.iarc.fr/ atlasoral_list.php?cat=B2\&lang=1

\section{Скрининг рака ротовой полости: актуальность \\ вопроса, текущее состояние проблемы \\ и перспективы развития (обзор литературы)}

А.И. Иващук, С.Л. Говорнян, В.Ю. Бодяка, Ю.Я. Чупровская Буковинский государственный медицинский университет,

Черновцы

Резюме. Данное исследование посвящено изучению проблемы рака ротовой полости, а также методам скрининга, существующим для этого вида онкологических заболеваний. Цель и объект исследования. Оценить методы скрининга, их специфичность и чувствительность, а также целесообразность и соответствие существующих методик мировым требованиям к скрининговым программам, а также установить перспективы дальнейшего научного поиска в направлении разработки адекватного скрининга. Методом исследования стал анализ литературных источников и поискданных, которые соответствуют указанной тематике в различных научно-методических базах. $\boldsymbol{B}$ результате исследования было установлено, что существующие попытки проведения как организованных, так и оппортунистических скрининговыхпрограмм показали свою неэффективность и не были приняты ни на одном из уровней организации системы здравоохранения. Основным методом скрининговых программ было проведение физикального обследования ротовой полости в сочетании с различными вспомогательными методами. Все эти методики показали недостаточную специфичность и чувствительность. Выводы. Ни один из известных скрининговых методов не соответствует требованиям и не является достаточно рентабельным, чувствительным и малоинвазивным. Таким образом, данное исследование подчеркивает важность поиска нового метода скрининга рака ротовой полости.

Ключевые слова: рак ротовой полости; скрининг; методы скрининга; скрининговые программы; факторы риска.

\section{Oral cancer screening: background, current status and prospects (literature review)}

O.I. Ivashchuk, S.L. Hovornyan, V.Y. Bodyaka, Yu.Ya. Chuprovska Bukovinian State Medical University, Chernivtsi

Summary. This research focuses on the study of oral cancer, as well as all available screening methods for this type of cancer. The aim of the research. Evaluate screening methods, their specificity and sensitivity, as well as the appropriateness and relevance of existing screening techniques to the global requirements for screening programs, and establish the prospects for further scientific study of oral cancer screening. The method of this research was the literature review and looking for data about above mentioned topic in different scientific and methodological bases. The result of this research show, that there is no successful try to provide an organized or opportunistic screening programs and none of them was accepted by any level of health care system. The main way of screening was a physical examination of oral cavity with different adjuvant methods, but all of them were not specific and sensitive enough. Conclusions. None of the known screening methods is compliant, workable, effective, sensitive or minimally invasive enough. Thus, this study highlights the importance of finding a new method of screening for oral cancer.

Key words: oral cancer; screening; screening methods; screening programs; risk factors.

Aдреса:

Говорнян Сергій Леонідович

58002, Чернівці, пл. Театральна, 2

Буковинський державний медичний університет

E-mail:hovornyan@bsmu.edu.ua Bukovinian State Medical University E-mail: hovornyan@bsmu.edu.ua 